\title{
Lessons Learned from Protective Immune Responses to Optimize Vaccines against Cryptosporidiosis
}

\author{
Maxime W. Lemieux ${ }^{1,2,+}$, Karine Sonzogni-Desautels ${ }^{1,3,+}$ and Momar Ndao ${ }^{1,4, *}$ \\ 1 National Reference Centre for Parasitology, Research Institute of the McGill University Health Centre, \\ McGill University, Montreal, QC H4A 3J1, Canada; maxime.lemieux@mail.mcgill.ca (M.W.L.); \\ karine.sonzogni-desautels@mail.mcgill.ca (K.S.-D.) \\ 2 Department of Medicine, Division of Experimental Medicine, Faculty of Medicine, McGill University, \\ Montreal, QC H4A 3J1, Canada \\ 3 Faculty of Agricultural and Environmental Sciences, Institute of Parasitology, McGill University, \\ Ste-Anne-de-Bellevue, QC H9X 3V9, Canada \\ 4 Department of Medicine, Division of Infectious Diseases, Faculty of Medicine, McGill University, \\ Montreal, QC H4A 3J1, Canada \\ * Correspondence: momar.ndao@mcgill.ca; Tel.: +1-514-934-1934 (ext. 44537); Fax: +1-514-934-8347 \\ + These authors have contributed equally to this work.
}

Received: 27 November 2017; Accepted: 22 December 2017; Published: 24 December 2017

\begin{abstract}
In developing countries, cryptosporidiosis causes moderate-to-severe diarrhea and kills thousands of infants and toddlers annually. Drinking and recreational water contaminated with Cryptosporidium spp. oocysts has led to waterborne outbreaks in developed countries. A competent immune system is necessary to clear this parasitic infection. A better understanding of the immune responses required to prevent or limit infection by this protozoan parasite is the cornerstone of development of an effective vaccine. In this light, lessons learned from previously developed vaccines against Cryptosporidium spp. are at the foundation for development of better next-generation vaccines. In this review, we summarize the immune responses elicited by naturally and experimentally-induced Cryptosporidium spp. infection and by several experimental vaccines in various animal models. Our aim is to increase awareness about the immune responses that underlie protection against cryptosporidiosis and to encourage promotion of these immune responses as a key strategy for vaccine development. Innate and mucosal immunity will be addressed as well as adaptive immunity, with an emphasis on the balance between $\mathrm{T}_{\mathrm{H}} 1 / \mathrm{T}_{\mathrm{H}} 2$ immune responses. Development of more effective vaccines against cryptosporidiosis is needed to prevent Cryptosporidium spp.-related deaths in infants and toddlers in developing countries.
\end{abstract}

Keywords: cryptosporidiosis; Cryptosporidium; immune response; infection; vaccine; innate immunity; mucosal immunity; adaptive immunity; $\mathrm{T}_{\mathrm{H}} 1$ immune response; $\mathrm{T}_{\mathrm{H}} 2$ immune response

\section{Introduction}

Among the causes of mortality worldwide, diarrheal-associated deaths are in the top 10 causes of mortality in humans and the fourth leading cause in children under 5 years of age (around 499,000 deaths every year) [1]. Human cryptosporidiosis caused by Cryptosporidium hominis and C. parvum is the second most common cause (following only rotavirus) of moderate-to-severe diarrhea in 0-11 month-old infants and the third most common in 12-23 month-old toddlers in sub-Saharan Africa and south Asia [2]. For example, in rural Bangladesh, 77\% of children less than 2 years old were infected with Cryptosporidium spp. [3]. This infection was associated with failure to thrive and impaired cognitive functions in young children in developing countries [3-5]. More worryingly, around 202,000 deaths are attributable to cryptosporidiosis among children younger 
than 24 months old in sub-Saharan Africa, India, Pakistan, Bangladesh, Nepal and Afghanistan [6]. Among these deaths, around 59,000 are in excess in comparison if these children were Cryptosporidium spp.-negative [6]. C. hominis was isolated in $77.8 \%$ of cryptosporidiosis cases in children in sub-Saharan Africa and south Asia, with C. parvum present in 9.9\% [6]. C. parvum-positive cases can arise from human-to-human transmission [6], but C. parvum is a zoonotic protozoan parasite and can also be transmitted from animal hosts to humans [7]. For this reason, veterinary students can sometimes get infected through contact with C. parvum-infected calves [8-10]. Also, C. parvum oocysts obtained from livestock can contaminate water [11], and Cryptosporidium spp. constitute a significant public health concern in developed and developing countries due to its ubiquitous nature [12]. C. hominis or C. parvum contamination of water can lead to foodborne outbreaks [7] following consumption of fruits and vegetables irrigated or washed with Cryptosporidium spp.-contaminated water [13]. Many waterborne outbreaks have been reported in developed countries following contamination with C. hominis or C. parvum oocysts of drinking (untreated surface water, water-treatment limitations, water-testing limitations, etc.) or recreational water (swimming pools, etc.) [14]. One of the most important waterborne outbreaks happened in Milwaukee, USA in 1993, in which 403,000 people showed symptoms of watery diarrhea following Cryptosporidium spp. infection $[14,15]$ and many immunocompromised people died of the infection [16]. While the source of the infection is still debated [17], filtration system of Milwaukee's water treatment plants was deficient and did not remove all oocysts from the treated water [15]. This outbreak cost USD 64.6 million in lost productivity and USD 31.7 million in medical costs [18]. Immunocompetent individuals usually recover spontaneously from a transient gastroenteritis characterized by watery diarrhea and abdominal cramps $[7,15,19]$. However, immunocompromised patients, such as HIV/AIDS patients, people under immunosuppressive treatments (cancer patients undergoing chemotherapy or patients with solid-organ transplants), patients with inheritable immunodeficiency syndromes (children with Severe Combined Immunodeficiency Syndrome (SCID)) and infants can develop chronic, severe and even life-threatening clinical signs [19]. AIDS patients were particularly at risk of lethal cryptosporidiosis before the availability of effective anti-retroviral therapies [20,21]. Recent advances in anti-retroviral therapy (ART) have markedly reduced the risk of cryptosporidiosis in HIV-infected individuals [22,23]. As a result, patients co-infected with HIV and Cryptosporidium spp. have much lower mortality rates compared to 15 years ago [24-26].

From a veterinary point of view, Cryptosporidium spp. infect a variety of mammals, including calves, dogs, cats, rabbits and birds [14,27]. Bovine cryptosporidiosis caused by C. parvum is a major problem in the dairy industry because infection is extremely prevalent [28-30] in newborn dairy calves and can cause life-threatening disease [31,32]. Because C. parvum is a zoonotic parasite and Cryptosporidium spp. complete the life cycle within a single individual [19], bovine cryptosporidiosis is also a public health concern. The risk is compounded by the fact that morbidity associated with infection in both humans and animals occurs at a very low parasite inoculum: $30 \mathrm{C}$. parvum oocysts are sufficient to cause a symptomatic human infection [33]. Despite extensive research on chemotherapy against Cryptosporidium spp., there is still a lack of curative treatments [34]. Moreover, no vaccine is available to prevent cryptosporidiosis in humans or animals, despite the urgent need [34]. The difficulty to develop efficient vaccines against Cryptosporidium spp. mostly comes from its unique life cycle which has already been reviewed [35]. Briefly, the oocysts excyst and sporozoites are released to infect intestinal epithelial cells (IECs) [36]. Sporozoites mature to become trophozoites and form type 1 meront (type 1 schizont) containing merozoite precursors [19]. Mature merozoites that become trophozoites complete the asexual cycle while those that become type 2 meronts continue to the sexual cycle of the parasite which will lead to production of infectious oocysts [19]. Because most stages of Cryptosporidium spp. life cycle occur inside IECs and are located intracellularly, but extracytoplasmically [19], surface proteins of sporozoites and merozoites are thought to be ideal candidate for vaccine development. However, the pathophysiology of cryptosporidiosis is not fully elucidated and developing an effective vaccine is a major challenge [37]. The aim of this review is to increase awareness of the immune 
responses that control Cryptosporidium spp. infection to be able to define appropriate targets in vaccine development.

\section{Innate Immunity}

The critical role of the innate immune response to $C$. parvum infection has been covered elsewhere [38,39]. Briefly, innate immunity is required for controlling the intensity of Cryptosporidium spp. infection [36]. After ingestion of Cryptosporidium spp. oocysts, sporozoites are released in the intestinal lumen and migrate to IECs; while IECs are the first physical barrier against infection, they also are the main target for Cryptosporidium spp. sporozoites $[19,36]$. Chemokines are first released by C. parvum-infected IECs to promote chemotaxis at the site of infection; chemokines induce migration of dendritic cells in the ileum and the draining lymph nodes [40] (Figure 1). Inflammatory monocytes will also migrate to the subepithelial space in response to $C$. parvum infection and secrete TNF $\alpha$ and IL-1 $\beta$ [41]. These cytokines will increase permeability, therefore weakening the integrity of the intestinal epithelial barrier [41]. Also, nitric oxide NO is important in C. parvum infection clearance and reduces oocyst shedding in chronically infected nude mice [42]. NO is produced independently of IFN $\gamma$ in Cryptosporidium spp. infections [43]. Inhibition of inducible nitric oxide synthase (iNOS) led to increased parasitism and oocyst shedding in C. parvum-infected piglets [44]. During C. parvum infection, the protective effect of iNOS depends on arginine availability in mice [42]. In fact, Leitch and $\mathrm{He}$ showed that supplementation with L-arginine decreases oocyst shedding in athymic nude mice [42]. IFN $\gamma$ mediated production of chemokines by IECs recruits dendritic cells which clear C. parvum infection [39]. IECs also release antimicrobial peptides to destroy free parasites or can enter apoptosis if C. parvum infection already occurred [36] (Figure 1). Infection of IECs by Cryptosporidium spp. activates the MyD88 and NF-kB signalling cascade through Toll-like receptors (TLRs); in particular, TLR2 and TLR4 induce the production of human $\beta$-defensin 2 to help clear parasites [45,46].

Mucosal immunity is important for clearance of Cryptosporidium spp., as reviewed elsewhere [35]. The activation of antigen-presenting cells such as macrophages and dendritic cells is also important in Cryptosporidium spp. infections [47-51]. Dendritic cells can clear Cryptosporidium spp. from the site of infection via activation of adaptive immune responses [51,52]. But, dendritic cells, neutrophils and IFN $\gamma$ are also important in Cryptosporidium spp. infection because they play a crucial role in pathogen recognition and clearance of the parasite through direct contact $[50,51,53,54]$ (Figure 1). The crucial role of mucosal natural killer (NK) cells (non-T, non-B lymphocytes [55]) in Cryptosporidium spp. infection is an active field of research [56-58]. The important contributions of NK cells and IFN $\gamma$ in innate immune responses against $C$. parvum infection have previously been reviewed [59]. Briefly, NK cells are an important source of IFN $\gamma$ in cryptosporidiosis and they are key players in controlling the infection in mice $[56,60]$. In the acute phase of infection, $C$. parvum sporozoites induce production of IL-12 by macrophages and dendritic cells [61]. IL-12 acts synergistically with IL-18 and TNF $\alpha$ to activate NK cells $[19,62,63]$ (Figure 1). Thus, the production of IFN $\gamma$ by NK cells and macrophages in response to Cryptosporidium spp. is promoted by IL-12 and IL-18 [64,65]. Secreted IFN $\gamma$ can inhibit C. paroum invasion and intracellular development by acting directly on enterocytes and preventing parasite invasion [50,54] (Figure 1). Moreover, NK cells can efficiently kill Cryptosporidium spp.-infected human IECs [58] by inducing programmed cell death via the action of released cytotoxic granules [62] (Figure 1).

Apart from its role in inducing IFN $\gamma$ production by NK cells, IL-18 also has a NK cell-independent role (Figure 1). Rag2 ${ }^{-/}$gammac $^{-/-}$adult mice (deficient for NK, T and B cells) can clear C. parvum infection due to NK cell-independent IFN $\gamma$ production [57]. In this case, IFN $\gamma$ is probably produced by IL-18- and IL-12-activated macrophages [57]. However, NK, T and B cell-deficient Rag2 $2^{-/-}$gammac $^{-/-}$adult or neonate mice have more severe $C$. parvum infections than $\mathrm{T}$ and B cell-deficient Rag2-/- adult mice [56]. Consequently, even if both NK cell-dependent and -independent IFN $\gamma$ have a protective role in innate immunity against $C$. parvum infection, presence of NK cells significantly helps to contain infection [56]. 


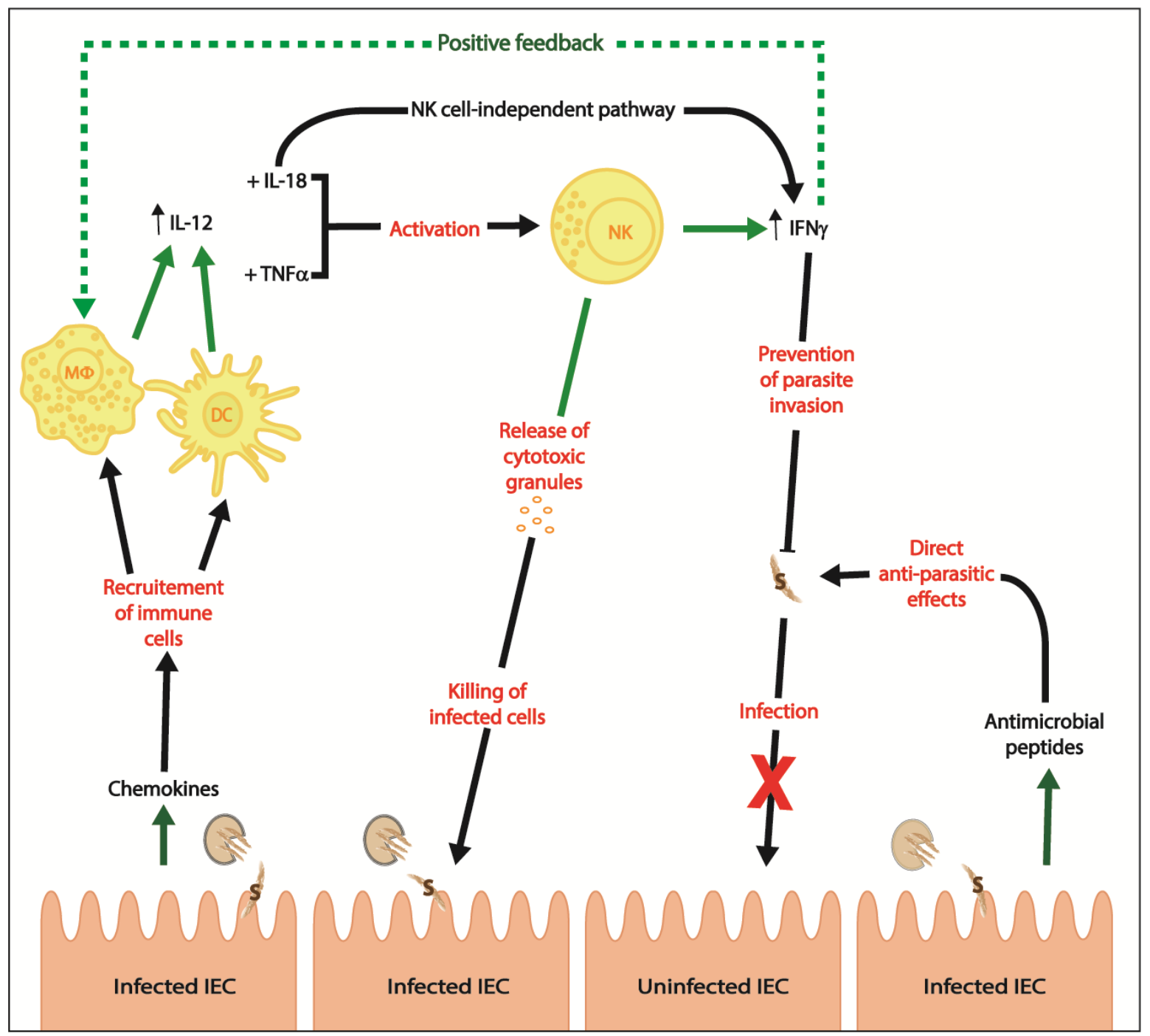

Figure 1. Innate immune responses during Cryptosporidium spp. infection. Green solid lines show release of molecules, green dotted line illustrates positive feedback, black solid lines present direction of effects and red wordings define effects. NK = NK cell, M $\Phi=$ macrophage, DC = dendritic cell, $\mathrm{S}=$ sporozoite and IEC $=$ intestinal epithelial cell.

The susceptibility of interferon gamma receptor knock-out (IFN $\gamma \mathrm{R}-\mathrm{KO}$ ) mice to Cryptosporidium spp. infection is an excellent example of the essential role of IFN $\gamma$ for the control of cryptosporidiosis [66-68]. SCID-IFN $\gamma$ KO mice have heavier infections than SCID mice [69] and IL-12KO mice are highly susceptible to Cryptosporidium spp. infection [70,71]. In addition, treatment of newborn SCID mice with anti-IL-12 neutralizing antibodies exacerbates cryptosporidiosis [64].

\section{Adaptive Immunity}

\subsection{Cell-Mediated Immune Responses}

The innate response is important for initial control of Cryptosporidium spp. infection, but adaptive immune responses are required for resolution of this disease [19,36]. The gut-associated lymphoid tissue (GALT) of the intestine is the main line of defense against pathogenic and commensal organisms of the gastrointestinal tract [72]. The intestinal environment contains a very diverse pool of antigens from food and microorganisms [73]. The mucosal immune system is therefore an important barrier to protect against pathogenic organisms and to confer tolerance against food antigens and the gut 
microbiota [74]. The gut immune responses therefore encompass high numbers of pro-inflammatory cells to prevent infection and regulatory $\mathrm{T}$ cells that regulate homeostasis [75]. Cryptosporidium spp. infection is more severe (potentially fatal) and longer lasting in immunocompromised individuals with defective adaptive immune responses [76,77]. The crucial role of T-cell responses in Cryptosporidium spp. infection is obvious when studying HIV-infected patients [78] and patients with an immunodeficiency affecting T-cells [76].

As reviewed [60], $\mathrm{CD} 4+\mathrm{T}$ cells are key actors in mounting adequate immune responses against cryptosporidiosis. Indeed, during the acute phase of infection involving innate immunity, CD4+ T cells are essential to clear Cryptosporidium spp. [19]. Cryptosporidium spp. infection is particularly frequent in AIDS patients with CD4+ T cell counts of $<100$ cells $/ \mu \mathrm{L}$ [79]. CD4+ T cells counts $<50$ cells $/ \mu \mathrm{L}$ are correlated with worse disease outcomes in immunocompromised patients [50,76,80-82]. $\mathrm{T}_{\mathrm{H}} 17$ cells constitute the first subset of CD4+ T helper cells to differentiate upon exposure of antigen-presenting cells to pathogens and are therefore important during the early stages of an infection [62]. $\mathrm{T}_{\mathrm{H}} 17$ cells differentiate from naive CD4+ T cells in presence of IL- 6 and TGF $\beta$ (produced by dendritic cells), but in the absence of IL-12 and IL-4 [62] (Figure 2). IL-23 stimulates $\mathrm{T}_{\mathrm{H}} 17$ cells to produce IL-17, but not IFN $\gamma$ or IL-4 [62]. Because IL-17 is involved in cytokine and chemokine secretion, which will have a chemotactic effect on neutrophils at the site of infection, IL-17 supports innate immunity against pathogens [62] (Figure 2). Among other $\mathrm{T}_{\mathrm{H}} 17$ cytokines, IL-17, IL-6, TNF $\alpha$, TGF $\beta$ and IL-23 are found in increased levels in the gut-associated lymphoid tissue and spleen of immunosuppressed BALB/c mice infected with C. parvum [83] (Figure 2).

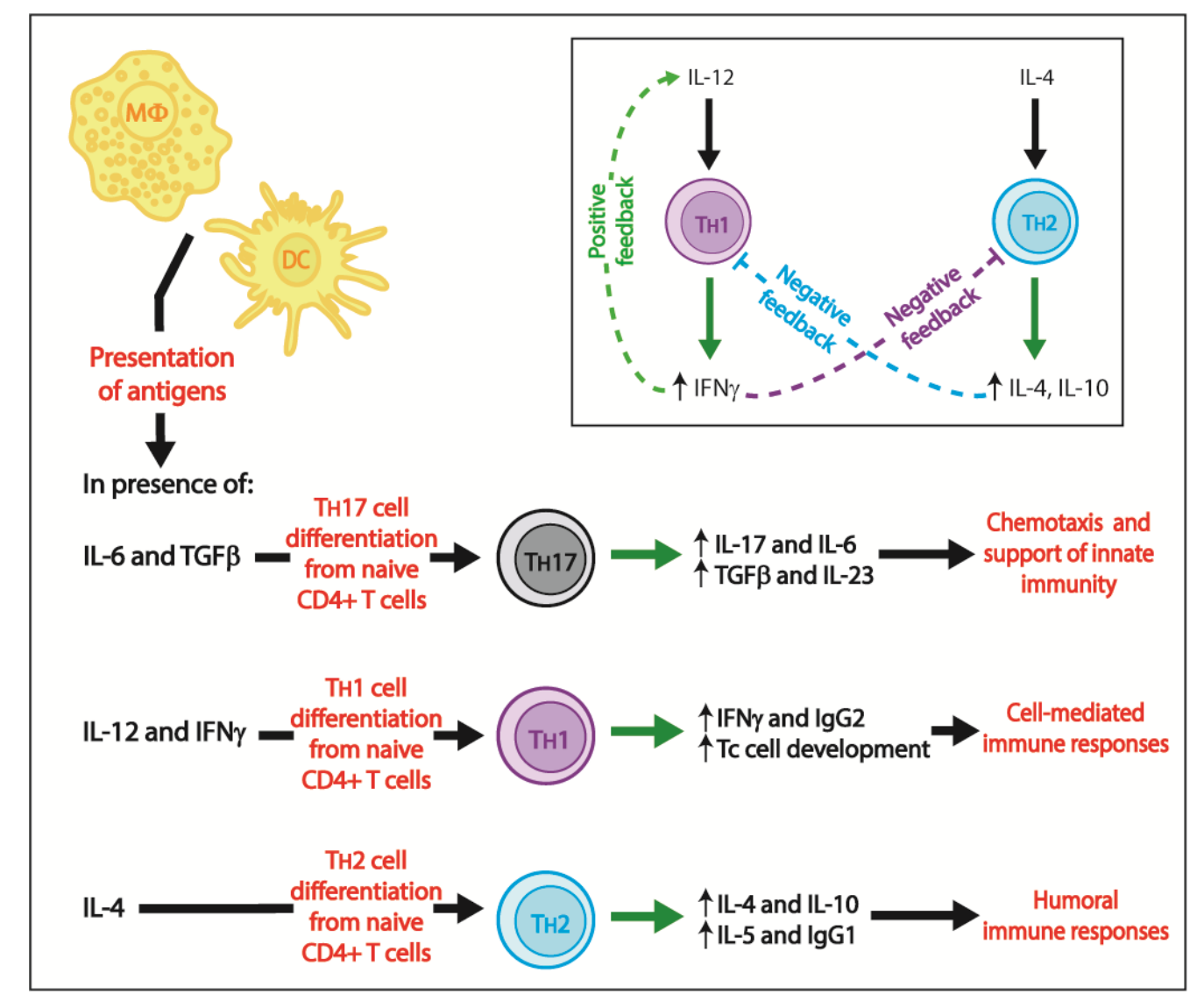

Figure 2. Adaptive immune responses during Cryptosporidium spp. infection. Green solid lines show release of molecules, green dotted line illustrates positive feedback, light blue and purple dotted lines represent negative feedbacks, black solid lines present direction of effects and red wordings define effects. $M \Phi=$ macrophage, $\mathrm{DC}=$ dendritic cell, $\mathrm{T}_{\mathrm{H}} 1=\mathrm{T}_{\mathrm{H}} 1 \mathrm{~T}$ cell, $\mathrm{T}_{\mathrm{H}} 2=\mathrm{T}_{\mathrm{H}} 2 \mathrm{~T}$ cell, $\mathrm{T}_{\mathrm{H}} 17=\mathrm{T}_{\mathrm{H}} 17 \mathrm{~T}$ cell. 
Promotion of cell-mediated immune responses and killing of infected cells resulted, in part, from macrophages and dendritic cells secretion of IL-12 and activated NK cells secretion of IFN $\gamma$ [84] (Figure 3). In fact, IL-12 and IFN $\gamma$ induce differentiation of naive CD4+ $\mathrm{T}$ cells to $\mathrm{T}_{\mathrm{H}} 1$ cells which will, among other effects, secrete IFN $\gamma$, produce IgG2 and promote differentiation of cytotoxic $\mathrm{T}$ cells from CD8+ precursors [84] (Figure 2). IFN $\gamma$ has a positive feedback on IL-12 secretion by activating macrophages, while having a negative feedback on the $\mathrm{T}_{\mathrm{H}} 2$ differentiation of naive $\mathrm{CD} 4+\mathrm{T}$ cells (Figure 2, insert); consequently, IFN $\gamma$ strongly promotes a $\mathrm{T}_{\mathrm{H}} 1$ environment [84]. In contrast, IL-4 induces differentiation of CD4+ $\mathrm{T}_{\mathrm{H}} 2$ cells which, among other effects, induce production of IgG1, activate eosinophils and secrete IL-5, IL-4 and IL-10 (Figure 2); IL-4 and IL-10 have a negative feedback on $T_{H} 1$ cells [84] (Figure 2, insert). There is therefore a balance between $T_{H} 1$ and $T_{H} 2$ immune responses; cytokines secreted in a $\mathrm{T}_{\mathrm{H}} 1$ environment inhibit $\mathrm{T}_{\mathrm{H}} 2$ differentiation and vice versa. During Cryptosporidium spp. infection, CD4+ intraepithelial lymphocytes (IELs) produce IFN $\gamma$ which is essential for innate immunity and adaptive $\mathrm{T}_{\mathrm{H}} 1$ immune responses and has a direct inhibitory effect on Cryptosporidium spp. development in host enterocytes $[39,60]$.

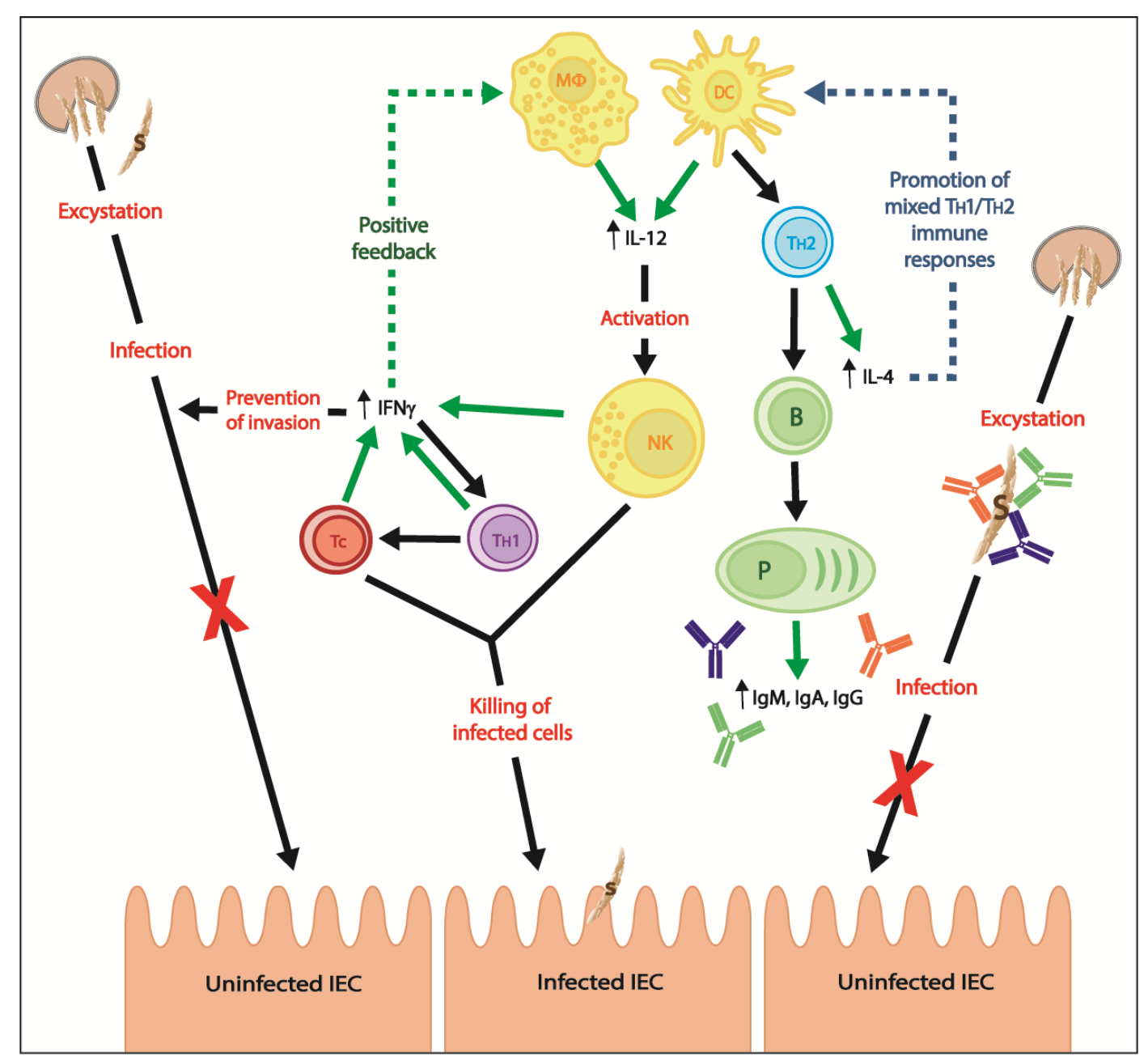

Figure 3. Protective immune responses during Cryptosporidium spp. infection and targets for vaccination. Green solid lines show release of molecules, green dotted line illustrates positive feedback, dark blue dotted line represents induction of mixed immune responses, black solid lines present direction of effects and red wordings define effects. $\mathrm{M} \Phi=$ macrophage, $\mathrm{DC}=$ dendritic cell, $\mathrm{NK}=\mathrm{NK}$ cell, $\mathrm{T}_{\mathrm{H}} 1=\mathrm{T}_{\mathrm{H}} 1 \mathrm{~T}$ cell, $\mathrm{T}_{\mathrm{H}} 2=\mathrm{T}_{\mathrm{H}} 2 \mathrm{~T}$ cell, $\mathrm{T} \mathrm{c}=$ cytotoxic $\mathrm{T}$ cell, $\mathrm{B}=\mathrm{B}$ cell, $\mathrm{P}=$ plasmocyte, $\mathrm{S}=$ sporozoite and IEC $=$ intestinal epithelial cell. 
The role of cytokines in Cryptosporidium spp. infection has been reviewed elsewhere [69]. Because of their importance in the immune response to $C$. parvum infection, they will briefly be reviewed here as well. As mentioned, IFN $\gamma$ has a vital role in controlling early phase infection as a major component of the innate immune response. However, this proinflammatory cytokine also has an important role in adaptive immunity [69]. IL-12 and IFN $\gamma$ promote development of naive CD4+ T cells into $\mathrm{T}_{\mathrm{H}} 1$ cells $[69,84]$ (Figure 2) which contribute to the killing of intracellular microorganisms, such as Cryptosporidium spp., by stimulating phagocytosis, neutrophil degranulation, and release of reactive oxygen species [69,85-87]. In addition, IL-4 has a protective role in Cryptosporidium spp. infection via IL-4-induced differentiation of naive CD4+ $\mathrm{T}$ cells into $\mathrm{T}_{\mathrm{H}} 2$ cells [69] (Figure 2). In C57BL/ 6 adult mice, IFN $\gamma$-producing CD4+ T cells were essential in the initial phases of $C$. parvum infection to control the severity of infection, while IL-4-producing CD4+ T cells were important to accelerate resolution of infection [88]. Therefore, even if cytokines associated with $\mathrm{T}_{\mathrm{H}} 1$ immune responses (e.g., IFN $\gamma$ and IL-12) are essential to clear $C$. parvum infection, some cytokines associated with $\mathrm{T}_{\mathrm{H}} 2$ immune responses (e.g., IL-4) have an important supporting role [89]. Wild-type, but not IFN $\gamma \mathrm{KO}$, mice treated with IL-4 neutralizing antibodies were less susceptible to $C$. parvum infection than untreated mice; IL-4 can therefore have an IFN $\gamma$-dependent protective role [89]. Thus, typical $\mathrm{T}_{\mathrm{H}} 2$ cytokines (i.e., IL-4) can potentially protect against cryptosporidiosis via $\mathrm{T}_{\mathrm{H}} 1$ immune responses [69] (Figure 3), as already reported for Leishmania major infection [90].

CD8+ T-cells are also important for clearance of the parasite. CD8+ T-cells also produce IFN $\gamma$ in response to infection (Figure 3) and potentially lyse Cryptosporidium spp.-infected IECs through the secretion of anti-parasitic cytotoxic granules [91]. However, CD8+ T-cells are not major actors in adaptive immune responses against Cryptosporidium spp. infection. C. parvum-infected SCID mouse recipients of splenocytes from immunocompetent mice cleared infection unless treated with anti-CD4+ or anti-INF $\gamma$ monoclonal antibodies, while anti-CD8+ monoclonal antibodies had no effect on the outcome [92]. SCID mice injected with IELs from immune BALB/c donors shed fewer oocysts and recovered more rapidly from $C$. muris infection; protection was abrogated by depletion of $\mathrm{CD} 4+\mathrm{T}$ cells, but not CD8+ T cells, from IELs [93]. In addition, BALB/c mice infected with C. muris and treated with anti-CD4 monoclonal antibodies had increased duration of patent infection and oocyst shedding, while mice treated with anti-CD8 monoclonal antibodies had only a moderate increase in oocyst shedding [94].

\subsection{Humoral Immune Responses}

Although the important role of cell-mediated immune responses is well-described in Cryptosporidium spp. infection, the importance of humoral immune responses is not fully understood [35]. As part of mucosal immune responses, B-cells represent a major subset of GALT immunity [95] and gut resident B-cells undergo V(D)J recombination to produce secretory IgA [96,97]. Also, systemic Cryptosporidium spp.-specific antibodies, notably serum IgM, IgA and IgG, are generated following infection [98-100]. Generally, these antibodies are insufficient to prevent and control Cryptosporidium spp. infection [98] and are not essential for recovery and clearance of the parasite [101]. However, antibodies may play a supportive role in protection, as hyperimmune bovine colostrum (HBC) has undeniable prophylactic and therapeutic effects [102-104]. In fact, many studies report that administration of hyperimmune colostrum/antibodies protects newborn animals against Cryptosporidium spp. infection [19]. The ability of antibodies to prevent cryptosporidiosis has not been thoroughly characterized in human medicine and lessons learned from veterinary medicine will be reviewed here.

\subsubsection{Bovine Cryptosporidiosis and Colostrum-Treatment of Calves}

As is true for human cryptosporidiosis, mucosal immune responses are also important for control of bovine cryptosporidiosis [105]. Lamina propria lymphocytes from C. parvum-infected calves express high levels of IFN $\gamma$ and IgG1+, and IgG2+ B lymphocytes are present in ileal villi in infected calves [105]. 
Also, IL-10 expression was reported by IELs of C. parvum-infected calves [106]. Peripheral blood mononuclear cells from calves recovering from $C$. parvum infection show $\mathrm{CD} 4+\mathrm{T}$ cell proliferation and IFN $\gamma$ expression [107]. Antibody titers in experimentally-infected calf serum peak 9 days post-infection (coinciding with the peak of oocyst shedding) and remain high thereafter [108]. Fecal IgM and IgA titers of experimentally-infected calves also peak 10 days post-infection ( 2 days after the peak of oocyst shedding) [109]. In another study, fecal IgM, IgA and IgG titers peaked 14 days post-infection and IgA titers remained high for at least 30 days post-infection while IgM and IgG titers decreased quickly [110]. Fecal antibody titers tend to raise when oocyst shedding increases and oocyst shedding stops when antibody titers peak [110].

Among C. parvum sporozoite surface proteins, p23 is one of the most immunogenic. Anti-p23 antibodies (IgM, IgA, IgG1 and IgG2) were detected in feces of $C$. paroum-experimentally-infected calves [111]. In that study, one calf which did not excrete detectable fecal anti-23 antibodies died of infection and another calf with pre-existing anti-p23 IgM antibodies did not shed oocysts [111]. Another study presented similar results for a calf with pre-existing anti-p23 antibodies [112]. In clinically normal newborn calves, anti-p23 IgM, IgA, IgG1 and IgG2 antibodies were detected in feces via passive transfer from colostrum [113], suggesting a maternal source of pre-existing anti-p23 antibodies.

Because newborn calves can get infected as soon as their day of birth [114], a promising approach against bovine cryptosporidiosis is vaccination of pregnant cows to engender production of HBC that will protect newborn dairy calves against C. parvum [115]. p23 is a promising antigen for vaccination against bovine cryptosporidiosis. HBC was produced by pregnant cows vaccinated using p23 and C. parvum-challenged HBC-treated calves had no diarrhea and oocyst shedding was reduced by 99.8\% [115]. In another study, HBC-treated calves showed delayed oocyst shedding with more than $90 \%$ reduction in oocysts shed [116]; also, no clinical sign of cryptosporidiosis was reported in the HBC-treated calves [116].

\subsubsection{Antibody Treatment of Immunocompromised Mice}

Several studies showing the ability of monoclonal antibodies to partially reduce oocyst shedding or intestinal parasite burden in immunocompromised mice support the importance of antibodies for protection against cryptosporidiosis. Oral gavage of $C$. parvum-infected SCID mice with an anti-SA-1 (C. parvum surface antigen-1) [117] IgM monoclonal antibody (mAb) reduced oocyst shedding [118]. A neutralizing anti-CSL (another C. parvum sporozoite ligand) $\mathrm{mAb}$ delivered by oral gavage reduced infection (as well as combination of mAbs raised against P23, GP25-200 and CSL) of adult IFN $\gamma$-depleted SCID mice [119]. IgA mAbs specific for P23 C. parvum surface protein passively immunized neonatal BALB/c mice and reduced intestinal parasite burden by up to $72 \%$ [120]. Oral treatment of SCID mice with anti-C. parvum IgY egg yolk antibody reduced parasite shedding [121]. An antibody-rich fraction extracted from HBC from cows immunized with C. parvum sonicated oocysts or sporozoites given orally to adult SCID mice resulted in reduced oocyst shedding and intestinal parasite burden [122]. Using hyperimmune ovine colostral whey, the intensity of infection in newborn NMRI mice was inversely proportional to the amount of antibody administered and number of doses [123]. Therefore, $\mathrm{mAbs}$ or hyperimmune colostrum might be an option for therapy of human cryptosporidiosis.

3.2.3. Treatment of Immunocompromised Cryptosporidium spp.-Infected Patients with Hyperimmune Bovine Colostrum

It is important to note that the importance of Cryptosporidium spp.-specific antibodies for protection against cryptosporidiosis might not be equal between humans and animal models. For example, high levels of fecal C. parvum-specific IgA and IgM antibodies following infection correlate with reduced oocyst shedding in C. parvum-infected athymic C57BL/6 nude mice [124]. IgA antibodies are present in Cryptosporidium spp.-infected AIDS patients, but this response is insufficient to protect against cryptosporidiosis $[98,125]$. In other words, anti-C. parvum antibodies alone cannot clear infection in 
immunocompromised Cryptosporidium spp.-infected patients without the support of CD4+ T cells [125]. Therefore, conclusions drawn from immunocompromised mouse models may not always be applicable for immunocompromised humans. In fact, contradictory results are reported in the literature. On one side, some studies suggest a partial protective role of antibodies from HBC against cryptosporidiosis in immunocompromised patients $[102,126,127]$ and HBC in concentrate powder form was an effective therapeutic approach in C. parvum-infected HIV patients as it significantly decreased stool weight and frequency [128]. On the other side, two studies showed that only some patients had reduced oocyst shedding after treatment [129] and that HBC had no protective effect compared to placebo to decrease stool volume or oocyst shedding [130].

\section{Vaccines against Cryptosporidium spp. Infection}

\subsection{DNA Vaccines and Subunit Vaccines}

Many types of vaccines exist, such as DNA vaccines, subunit vaccines, live-attenuated vaccines and vector vaccines $[131,132]$. Many promising vaccine approaches for cryptosporidiosis have been reviewed elsewhere [19,35,101]; briefly, some DNA and subunit vaccine candidates will be reviewed here. DNA vaccines encoding some surface proteins of C. parvum (such as Cp12 and Cp21 [133] or cp15 and p23 [134] or CP15/60 [135]) lead to protective immune responses via production of high IgG levels [133,134], elevated $\mathrm{T}_{\mathrm{H}} 1$ cytokines [134] and/or increase in the numbers of CD4+ and CD8+ $\mathrm{T}$ cells [133]. Protection from DNA vaccines resulted in up to $77.5 \%$ reduction in oocyst shedding after challenge $[133,134]$.

Subunit vaccines have been commonly used in vaccine development against cryptosporidiosis and several immunodominant proteins have been identified as potential vaccine candidates [136]. As mentioned previously, pregnant cows were vaccinated with $C$. parvum sporozoite p23 surface protein and resulting HBC was protective for C. paroum-challenged calves [115]. Also, in another study, anti-P23 HBC-treated calves showed no clinical sign of cryptosporidiosis and reduced and delayed oocyst shedding [116]. HBC from pregnant cows immunized with CP15/60 recombinant protein successfully transferred antibodies to calves via colostrum intake; however, challenge of treated calves was not presented [137]. In mice, divalent recombinant $C \mathrm{p} 15-23$ led to significant antibody and $\mathrm{T}_{\mathrm{H}} 1$ cytokine production and elevated numbers of $\mathrm{CD} 4+$, but did confer only partial protection against $C$. parvum challenge [138].

\subsection{Live-Attenuated Vaccine}

Live-attenuated vaccines have historically been shown to be best at eliciting long lasting memory immune responses, whereas subunit vaccines elicit a more modest memory response, often requiring subsequent booster doses to achieve long lasting immunity [132]. Attenuated vaccines were first developed for viral and bacterial pathogens because of the inherent complexity of parasitic organisms; however, some vaccine development is ongoing for a few pathogenic parasites [139].

Live-attenuated vaccines elicit strong $\mathrm{T}_{\mathrm{H}} 1$ biased immune responses and offer protective cell-mediated immunity [132]. Several live-attenuated vaccines have been developed against protozoan parasites causing enteric disease, i.e., Eimeria $[140,141]$. Early studies showed that chickens receiving irradiated E. maxima oocysts were protected against coccidiosis-induced weight loss [142]. Also, live-attenuated Toxoplasma gondii induced protective immunity against toxoplasmosis in sheep for at least 6 months $[143,144]$. In addition, live vaccines against another parasite, Leishmania spp., have recently been studied [145]. A non-pathogenic species, L. tarentolae, elicits strong protective $\mathrm{T}_{\mathrm{H}} 1$ immune responses in mice against $L$. donovani [146]. Similar responses were observed in mice vaccinated with attenuated L. donovani [147]. Although this approach is promising, a live-attenuated vaccine may not be ideal for cryptosporidiosis due to its host requirement for replication [19]. This is further exacerbated by the lack of a continuous in vitro culture system allowing oocyst production for Cryptosporidium spp. [148]. Nonetheless, $\gamma$-irradiation has been used on Cryptosporidium spp. oocysts 
or sporozoites to reduce their viability and infectivity [149]. Irradiated C. parvum oocysts were shown to elicit protective immune responses in calves challenged at 3 weeks post-vaccination [150].

\subsection{Vaccine Vectors}

Vaccine vectors came into play in the early 1990s [151], but the first vaccine vector to be licensed is a chimeric yellow fever attenuated strain in 2010 [152]. A vaccine against Cryptosporidium spp. should stimulate mucosal immune responses by promoting uptake of antigens by microfold cells (M cells), specialized epithelial cells adjacent to enterocytes that facilitate the passage of antigens to Peyer's patches [62]. Intestinal antigen delivery to the $\mathrm{M}$ cells could be achieved using a vaccine delivery system such as attenuated bacterial or viral vectors $[153,154]$. To our knowledge, no viral vectors have been used in candidate vaccines for Cryptosporidium spp., but several live bacterial vectors have been studied [155-157].

Bacterial vaccine vectors are very promising for vaccine antigen delivery as they can elicit protective immune responses against bacterial, viral and protozoan pathogens in both mice and humans [158]. For instance, delivery of influenza hemagglutinin and neuraminidase using an attenuated $S$. typhimurium vector induced strong protective cellular and humoral immunity against Influenza A virus [159]. Also, delivery of Trichinella spiralis DNA using an attenuated S. typhimurium elicited protective mixed $\mathrm{T}_{\mathrm{H}} 1 / \mathrm{T}_{\mathrm{H}} 2$ immune responses in mice [160]. Moreover, Plasmodium falciparum tCSP genes fused to secretion signals were delivered through $S$. typhimurium and boosted with a DNA vaccine and elicited strong cellular $\mathrm{T}_{\mathrm{H}} 1$ immune responses [161]. Overall, the many advantages of this vaccine approach (ease of administration and low production cost) engender excellent candidates for vaccine development [162]. Fusing the protein of interest to a secretion signal and a chaperone binding domain of S. enterica allows secretion of the antigen of interest through the type III secretion system-dependent for delivery to antigen-presenting cells [163].

A number of attenuated S. typhimurium vectors expressing Cryptosporidium spp. antigens have been generated [155-157]. Promising humoral and cellular immune responses were obtained from a prime boost technique with Salmonella enterica serovar Typhi CVD-908-htrA and cytolysin A (ClyA) fused to either $C$. hominis apyrase (CApy), profilin or Cp15 [155]. In mice, these vaccines elicited strong humoral immune responses with high production of IgG1 and IgG2b and interesting cellular immune responses via production of different levels of several cytokines (IFN $\gamma$, IL-2, IL-6, and IL-12) [155]. Attenuated Salmonella enterica serovar Typhimurium vaccine strain SL3261 expressing C. parvum Cp23 or $\mathrm{Cp} 40$ fused to fragment $\mathrm{C}$ of tetanus toxin elicited humoral immune responses when delivered as an oral boost after subcutaneous immunization with cp23 or cp40 DNA [156]. An attenuated Salmonella enterica serovar Typhi CVD 908-htrA expressing Cp15 delivered intranasally in mice showed high production of IL-6, IFN $\gamma$ and Cp15-specific IgG [157]. However, vaccination did not result in protection against $C$. parvum infection in mice [157]. Another vector system used for Cryptosporidium spp. antigen delivery is $T$. gondii [164]. Immunization of mice with $T$. gondii expressing $C$. parvum P23 antigen resulted in high levels of serum IgG, predominantly IgG1, which is characteristic of a $\mathrm{T}_{\mathrm{H}} 2$ immune response [164,165]. In another study, Lactobacillus casei Zhang (a probiotic bacterium [166]) was used to deliver C. parvum P23 to mice and generated increased levels of IFN $\gamma$, IL-6, serum IgG and fecal $\operatorname{IgA}[167]$.

Overall, vaccine vectors show promising immunological results and appear to be an interesting option for vaccine development against cryptosporidiosis. Although one challenge study showed no protection after vaccination [157], more studies using various vectors and immunogens are needed to assess the true potential of this method. It will be very interesting to determine if they show better protection against Cryptosporidium spp. infection than their non-vector strategies. The high carrying capacity of vectors is also an advantage, as they can deliver multiple antigens and even adjuvants to the target site [168]. Vaccine vectors can also be used either alone or in combination with DNA or antigen-based vaccine candidates as a 'prime-pull' method [155,161]. 


\subsection{Prime-Pull Vaccine Approach}

The prime-pull vaccine approach primes the immune system with an antigen to elicit strong systemic T cells immune responses and then 'pulls' $\mathrm{T}$ cell immune responses at the site of infection using local delivery of immunogens and/or pro-inflammatory molecules to elicit local protective and long-lasting memory responses [169]. In other words, the 'prime' immunization using intramuscular delivery of antigen(s) elicits systemic $\mathrm{T}$ cell immune responses while the 'pull' immunization allows for the formation of a strong pool of tissue-resident T cells [169]. As mentioned above, the prime-pull approach has been used in combination with vaccine vectors against Cryptosporidium spp. infection in various delivery schedules and methods [155-157]. In some studies, C. parvum DNA was used to 'prime' mice and the C. parvum antigen-expressing Salmonella spp. vector was given as a boost [156]. In other studies, the Salmonella spp. vector vaccine was given as a 'prime' and then boosted with recombinant protein given intraperitoneally $[155,157]$. Overall, the prime-pull method elicits much stronger immune responses than the vector or the antigen alone [155-157].

\section{Conclusions and Future Directions}

As Cryptosporidium spp.-infected immunocompetent individuals only present with transient diarrhea while immunocompromised patients and infants in developing countries can have very severe and life-threatening cryptosporidiosis, the competency of the host immune system to raise adequate immune responses is the key factor to clear Cryptosporidium spp. parasites. The pathogenesis of cryptosporidiosis is incompletely understood because this protozoan parasite induces complex host immune responses. Innate immunity can contain $C$. parvum infection via the action of IL-18- and IL-12-activated macrophages and NK cells which induce NK cells-dependent and NK cells-independent IFN $\gamma$ production (Figures 1 and 3). Adaptive immunity will clear C. parvum infection via the action of $\mathrm{CD} 4+\mathrm{T}_{\mathrm{H}} 1$ cell-mediated immune responses which induce IFN $\gamma$ production and killing of infected IEC; $\mathrm{T}_{\mathrm{H}} 2$ immune responses and humoral immunity have a non-negligible supportive role (Figures 2 and 3 ).

To sum up, protective immune responses against Cryptosporidium spp. infection require strong mucosal $\mathrm{T}_{\mathrm{H}} 1$ cell-mediated immune responses with the support of a $\mathrm{T}_{\mathrm{H}}$ 2-dependant Cryptosporidium spp.-specific humoral immunity (Figure 3). A vaccine that induces such immune responses, if safe for use in children and immunocompromised individuals, should be the best candidate to prevent cryptosporidiosis. Furthermore, because Cryptosporidium spp. infects the intestinal epithelia, a vaccine against cryptosporidiosis would ideally elicit strong mucosal immune responses [35]. Vaccine vectors using the 'prime-pull' approach represent a new era in vaccine development and we believe that these new techniques have the potential to elicit more targeted immune responses and localized protection against Cryptosporidium spp. infection [156]. Results from ongoing studies will determine potential of this new vaccine approach against Cryptosporidium spp. infection.

Acknowledgments: The authors sincerely thank Timothy Geary for manuscript editing. The National Reference Centre for Parasitology is supported by Public Health Agency of Canada/National Microbiology Laboratory grant MOA 4500299739, the Foundation of the Montreal General Hospital, the Foundation of the McGill University Health Centre and the Research Institute of the McGill University Health Centre. We are also grateful to Fonds de recherche du Québec-Nature et technologies for Fellowship support and to the FRQNT-Centre for Host-Parasite Interactions for bridging funds.

Author Contributions: Maxime W. Lemieux and Karine Sonzogni-Desautels reviewed the existing literature and wrote the manuscript under the supervision of Momar Ndao. Momar Ndao edited the manuscript. All authors approved the final version of the manuscript.

Conflicts of Interest: The authors declare no conflicts of interest. The sponsors had no role in the writing of the manuscript. 


\section{References}

1. Troeger, C.; Forouzanfar, M.; Rao, P.C.; Khalil, I.; Brown, A.; Reiner, R.C.; Fullman, N.; Thompson, R.L.; Abajobir, A.; Ahmed, M.; et al. Estimates of global, regional, and national morbidity, mortality, and aetiologies of diarrhoeal diseases: A systematic analysis for the Global Burden of Disease Study 2015. Lancet Infect. Dis. 2017, 17, 909-948. [CrossRef]

2. Kotloff, K.L.; Nataro, J.P.; Blackwelder, W.C.; Nasrin, D.; Farag, T.H.; Panchalingam, S.; Wu, Y.; Sow, S.O.; Sur, D.; Breiman, R.F.; et al. Burden and aetiology of diarrhoeal disease in infants and young children in developing countries (the Global Enteric Multicenter Study, GEMS): A prospective, case-control study. Lancet 2013, 382, 209-222. [CrossRef]

3. Korpe, P.S.; Haque, R.; Gilchrist, C.; Valencia, C.; Niu, F.; Lu, M.; Ma, J.Z.; Petri, S.E.; Reichman, D.; Kabir, M.; et al. Natural history of cryptosporidiosis in a longitudinal study of slum-dwelling Bangladeshi children: Association with severe malnutrition. PLoS Negl. Trop. Dis. 2016, 10, e0004564. [CrossRef] [PubMed]

4. Checkley, W.; Epstein, L.D.; Gilman, R.H.; Black, R.E.; Cabrera, L.; Sterling, C.R. Effects of Cryptosporidium parvum infection in peruvian children: Growth faltering and subsequent catch-up growth. Am. J. Epidemiol. 1998, 148, 497-506. [CrossRef] [PubMed]

5. Guerrant, D.I.; Moore, S.R.; Lima, A.A.; Patrick, P.D.; Schorling, J.B.; Guerrant, R.L. Association of early childhood diarrhea and cryptosporidiosis with impaired physical fitness and cognitive function four-seven years later in a poor urban community in northeast Brazil. Am. J. Trop. Med. Hyg. 1999, 61, 707-713. [CrossRef] [PubMed]

6. Sow, S.O.; Muhsen, K.; Nasrin, D.; Blackwelder, W.C.; Wu, Y.; Farag, T.H.; Panchalingam, S.; Sur, D.; Zaidi, A.K.; Faruque, A.S.; et al. The burden of Cryptosporidium diarrheal disease among children $<24$ months of age in moderate/high mortality regions of sub-Saharan Africa and south Asia, utilizing data from the Global Enteric Multicenter Study (GEMS). PLoS Negl. Trop. Dis. 2016, 10, e0004729. [CrossRef] [PubMed]

7. Ryan, U.; Zahedi, A.; Paparini, A. Cryptosporidium in humans and animals-A one health approach to prophylaxis. Parasite Immunol. 2016, 38, 535-547. [CrossRef] [PubMed]

8. Levine, J.F.; Levy, M.G.; Walker, R.L.; Crittenden, S. Cryptosporidiosis in veterinary students. J. Am. Vet. Med. Assoc. 1988, 193, 1413-1414. [PubMed]

9. Preiser, G.; Preiser, L.; Madeo, L. An outbreak of cryptosporidiosis among veterinary science students who work with calves. J. Am. Coll. Health 2003, 51, 213-215. [CrossRef] [PubMed]

10. Gait, R.; Soutar, R.H.; Hanson, M.; Fraser, C.; Chalmers, R. Outbreak of cryptosporidiosis among veterinary students. Vet. Rec. 2008, 162, 843-845. [CrossRef] [PubMed]

11. Ruecker, N.J.; Braithwaite, S.L.; Topp, E.; Edge, T.; Lapen, D.R.; Wilkes, G.; Robertson, W.; Medeiros, D.; Sensen, C.W.; Neumann, N.F. Tracking host sources of Cryptosporidium spp. in raw water for improved health risk assessment. Appl. Environ. Microbiol. 2007, 73, 3945-3957. [CrossRef] [PubMed]

12. Villeneuve, A. Les Zoonoses Parasitaires: L'infection Chez les Animaux et Chez L'hommes; Presses de l'Université de Montréal: Montréal, QC, Canada, 2003; 499p, ISBN 2760618633.

13. Dixon, B.; Parrington, L.; Cook, A.; Pollari, F.; Farber, J. Detection of Cyclospora, Cryptosporidium, and Giardia in ready-to-eat packaged leafy greens in Ontario, Canada. J. Food Prot. 2013, 76, 307-313. [CrossRef] [PubMed]

14. Chalmers, R.M. Waterborne outbreaks of cryptosporidiosis. Annali Dell'istituto Superiore di Sanita 2012, 48, 429-446. [CrossRef] [PubMed]

15. Mac Kenzie, W.R.; Hoxie, N.J.; Proctor, M.E.; Gradus, M.S.; Blair, K.A.; Peterson, D.E.; Kazmierczak, J.J.; Addiss, D.G.; Fox, K.R.; Rose, J.B.; et al. A massive outbreak in Milwaukee of cryptosporidium infection transmitted through the public water supply. N. Engl. J. Med. 1994, 331, 161-167. [CrossRef] [PubMed]

16. Hoxie, N.J.; Davis, J.P.; Vergeront, J.M.; Nashold, R.D.; Blair, K.A. Cryptosporidiosis-associated mortality following a massive waterborne outbreak in Milwaukee, Wisconsin. Am. J. Public Health 1997, 87, $2032-2035$. [CrossRef] [PubMed]

17. Zhou, L.; Singh, A.; Jiang, J.; Xiao, L. Molecular surveillance of Cryptosporidium spp. in raw wastewater in Milwaukee: Implications for understanding outbreak occurrence and transmission dynamics. J. Clin. Microbiol. 2003, 41, 5254-5257. [CrossRef] [PubMed] 
18. Corso, P.S.; Kramer, M.H.; Blair, K.A.; Addiss, D.G.; Davis, J.P.; Haddix, A.C. Cost of illness in the 1993 waterborne Cryptosporidium outbreak, Milwaukee, Wisconsin. Emerg. Infect. Dis. 2003, 9, 426-431. [CrossRef] [PubMed]

19. Fayer, R.; Xiao, L. Cryptosporidium and Cryptosporidiosis, 2nd ed.; CRC Press: Boca Raton, FL, USA; IWA Publishing: Boca Raton, FL, USA, 2008; 560p, ISBN 1420052268.

20. Armson, A.; Thompson, R.C.; Reynoldson, J.A. A review of chemotherapeutic approaches to the treatment of cryptosporidiosis. Expert Rev. Anti-Infect. Ther. 2003, 1, 297-305. [CrossRef] [PubMed]

21. Tzipori, S.; Widmer, G. A hundred-year retrospective on cryptosporidiosis. Trends Parasitol. 2008, 24, $184-189$. [CrossRef] [PubMed]

22. Ho, D.D.; Neumann, A.U.; Perelson, A.S.; Chen, W.; Leonard, J.M.; Markowitz, M. Rapid turnover of plasma virions and CD4 lymphocytes in HIV-1 infection. Nature 1995, 373, 123-126. [CrossRef] [PubMed]

23. Lok, J.J.; Bosch, R.J.; Benson, C.A.; Collier, A.C.; Robbins, G.K.; Shafer, R.W.; Hughes, M.D.; Team, A. Long-term increase in CD4+ T-cell counts during combination antiretroviral therapy for HIV-1 infection. AIDS 2010, 24, 1867-1876. [CrossRef] [PubMed]

24. Zardi, E.M.; Picardi, A.; Afeltra, A. Treatment of cryptosporidiosis in immunocompromised hosts. Chemotherapy 2005, 51, 193-196. [CrossRef] [PubMed]

25. Grube, H.; Ramratnam, B.; Ley, C.; Flanigan, T.P. Resolution of AIDS associated cryptosporidiosis after treatment with indinavir. Am. J. Gastroenterol. 1997, 92, 726. [PubMed]

26. Mele, R.; Morales, M.A.G.; Tosini, F.; Pozio, E. Indinavir reduces Cryptosporidium parvum infection in both in vitro and in vivo models. Int. J. Parasitol. 2003, 33, 757-764. [CrossRef]

27. Bowman, D.D.; Georgi, J.R. Georgis' Parasitology for Veterinarians, 10th ed.; Elsevier: St. Louis, MO, USA, 2014; 477p, ISBN 9781455740062.

28. Ruest, N.; Faubert, G.M.; Couture, Y. Prevalence and geographical distribution of Giardia spp. and Cryptosporidium spp. in dairy farms in Quebec. Can. Vet. J. 1998, 39, 697-700. [PubMed]

29. Santin, M.; Trout, J.M.; Xiao, L.; Zhou, L.; Greiner, E.; Fayer, R. Prevalence and age-related variation of Cryptosporidium species and genotypes in dairy calves. Vet. Parasitol. 2004, 122, 103-117. [CrossRef] [PubMed]

30. Xiao, L.; Zhou, L.; Santin, M.; Yang, W.; Fayer, R. Distribution of Cryptosporidium parvum subtypes in calves in eastern United States. Parasitol. Res. 2007, 100, 701-706. [CrossRef] [PubMed]

31. Institut de l'élevage. Maladies Des Bovins, 3rd ed.; Éditions France Agricole: Paris, France, 2000; 540p, ISBN 2855570484.

32. Tzipori, S. Cryptosporidiosis in animals and humans. Microbiol. Rev. 1983, 47, 84-96. [PubMed]

33. DuPont, H.L.; Chappell, C.L.; Sterling, C.R.; Okhuysen, P.C.; Rose, J.B.; Jakubowski, W. The infectivity of Cryptosporidium parvum in healthy volunteers. N. Engl. J. Med. 1995, 332, 855-859. [CrossRef] [PubMed]

34. Striepen, B. Parasitic infections: Time to tackle cryptosporidiosis. Nature 2013, 503, 189-191. [CrossRef] [PubMed]

35. Ludington, J.G.; Ward, H.D. Systemic and mucosal immune responses to Cryptosporidium-Vaccine development. Curr. Trop. Med. Rep. 2015, 2, 171-180. [CrossRef] [PubMed]

36. Laurent, F.; Lacroix-Lamande, S. Innate immune responses play a key role in controlling infection of the intestinal epithelium by Cryptosporidium. Int. J. Parasitol. 2017, 47, 711-721. [CrossRef] [PubMed]

37. Kothavade, R.J. Challenges in understanding the immunopathogenesis of Cryptosporidium infections in humans. Eur. J. Clin. Microbiol. Infect. Dis. 2011, 30, 1461-1472. [CrossRef] [PubMed]

38. Menzies, F.M.; Macphail, D.; Henriquez, F.L. The role of chemokines and their receptors during protist parasite infections. Parasitology 2016, 143, 1890-1901. [CrossRef] [PubMed]

39. Lantier, L.; Lacroix-Lamande, S.; Potiron, L.; Metton, C.; Drouet, F.; Guesdon, W.; Gnahoui-David, A.; Le Vern, Y.; Deriaud, E.; Fenis, A.; et al. Intestinal CD103+ dendritic cells are key players in the innate immune control of Cryptosporidium parvum infection in neonatal mice. PLoS Pathog. 2013, 9, e1003801. [CrossRef] [PubMed]

40. Auray, G.; Lacroix-Lamande, S.; Mancassola, R.; Dimier-Poisson, I.; Laurent, F. Involvement of intestinal epithelial cells in dendritic cell recruitment during C. parvum infection. Microbes Infect. Inst. Pasteur 2007, 9, 574-582. [CrossRef] [PubMed]

41. De Sablet, T.; Potiron, L.; Marquis, M.; Bussiere, F.I.; Lacroix-Lamande, S.; Laurent, F. Cryptosporidium parvum increases intestinal permeability through interaction with epithelial cells and IL-1beta and TNFalpha released by inflammatory monocytes. Cell. Microbiol. 2016, 18, 1871-1880. [CrossRef] [PubMed] 
42. Leitch, G.J.; He, Q. Arginine-derived nitric oxide reduces fecal oocyst shedding in nude mice infected with Cryptosporidium parvum. Infect. Immun. 1994, 62, 5173-5176. [PubMed]

43. Nordone, S.K.; Gookin, J.L. Lymphocytes and not IFN-gamma mediate expression of iNOS by intestinal epithelium in murine cryptosporidiosis. Parasitol. Res. 2010, 106, 1507-1511. [CrossRef] [PubMed]

44. Gookin, J.L.; Chiang, S.; Allen, J.; Armstrong, M.U.; Stauffer, S.H.; Finnegan, C.; Murtaugh, M.P. NF-kappaB-mediated expression of iNOS promotes epithelial defense against infection by Cryptosporidium parvum in neonatal piglets. Am. J. Physiol. Gastrointest. Liv. Physiol. 2006, 290, G164-G174. [CrossRef] [PubMed]

45. Zaalouk, T.K.; Bajaj-Elliott, M.; George, J.T.; McDonald, V. Differential regulation of beta-defensin gene expression during Cryptosporidium parvum infection. Infect. Immun. 2004, 72, 2772-2779. [CrossRef] [PubMed]

46. Chen, X.-M.; O’Hara, S.P.; Nelson, J.B.; Splinter, P.L.; Small, A.J.; Tietz, P.S.; Limper, A.H.; LaRusso, N.F. Multiple TLRs are expressed in human cholangiocytes and mediate host epithelial defense responses to Cryptosporidium parvum via activation of NF-kappaB. J. Immunol. 2005, 175, 7447-7456. [CrossRef] [PubMed]

47. Eriksson, M.; Meadows, S.K.; Basu, S.; Mselle, T.F.; Wira, C.R.; Sentman, C.L. TLRs mediate IFN-gamma production by human uterine NK cells in endometrium. J. Immunol. 2006, 176, 6219-6224. [CrossRef] [PubMed]

48. Gelman, A.E.; Zhang, J.; Choi, Y.; Turka, L.A. Toll-like receptor ligands directly promote activated CD4+ T-cell survival. J. Immunol. 2004, 172, 6065-6073. [CrossRef] [PubMed]

49. Rahman, A.H.; Taylor, D.K.; Turka, L.A. The contribution of direct TLR signaling to T-cell responses. Immunol. Res. 2009, 45, 25-36. [CrossRef] [PubMed]

50. Borad, A.; Ward, H. Human immune responses in cryptosporidiosis. Future Microbiol. 2010, 5, 507-519. [CrossRef] [PubMed]

51. Perez-Cordon, G.; Yang, G.; Zhou, B.; Nie, W.; Li, S.; Shi, L.; Tzipori, S.; Feng, H. Interaction of Cryptosporidium parvum with mouse dendritic cells leads to their activation and parasite transportation to mesenteric lymph nodes. Pathog. Dis. 2014, 70, 17-27. [CrossRef] [PubMed]

52. Bedi, B.; McNair, N.N.; Mead, J.R. Dendritic cells play a role in host susceptibility to Cryptosporidium parvum infection. Immunol. Lett. 2014, 158, 42-51. [CrossRef] [PubMed]

53. Leav, B.A.; Yoshida, M.; Rogers, K.; Cohen, S.; Godiwala, N.; Blumberg, R.S.; Ward, H. An early intestinal mucosal source of gamma interferon is associated with resistance to and control of Cryptosporidium parvum infection in mice. Infect. Immun. 2005, 73, 8425-8428. [CrossRef] [PubMed]

54. Pollok, R.C.; Farthing, M.J.; Bajaj-Elliott, M.; Sanderson, I.R.; McDonald, V. Interferon gamma induces enterocyte resistance against infection by the intracellular pathogen Cryptosporidium parvum. Gastroenterology 2001, 120, 99-107. [CrossRef] [PubMed]

55. Lodoen, M.B.; Lanier, L.L. Natural killer cells as an initial defense against pathogens. Curr. Opin. Immunol. 2006, 18, 391-398. [CrossRef] [PubMed]

56. Barakat, F.M.; McDonald, V.; Di Santo, J.P.; Korbel, D.S. Roles for NK cells and an NK cell-independent source of intestinal gamma interferon for innate immunity to Cryptosporidium parvum infection. Infect. Immun. 2009, 77, 5044-5049. [CrossRef] [PubMed]

57. Choudhry, N.; Petry, F.; van Rooijen, N.; McDonald, V. A protective role for interleukin 18 in interferon gamma-mediated innate immunity to Cryptosporidium parvum that is independent of natural killer cells. J. Infect. Dis. 2012, 206, 117-124. [CrossRef] [PubMed]

58. Dann, S.M.; Wang, H.C.; Gambarin, K.J.; Actor, J.K.; Robinson, P.; Lewis, D.E.; Caillat-Zucman, S.; White, A.C., Jr. Interleukin-15 activates human natural killer cells to clear the intestinal protozoan Cryptosporidium. J. Infect. Dis. 2005, 192, 1294-1302. [CrossRef] [PubMed]

59. McDonald, V.; Korbel, D.S.; Barakat, F.M.; Choudhry, N.; Petry, F. Innate immune responses against Cryptosporidium parvum infection. Parasite Immunol. 2013, 35, 55-64. [CrossRef] [PubMed]

60. McDonald, V. Host cell-mediated responses to infection with Cryptosporidium. Parasite Immunol. 2000, 22, 597-604. [CrossRef] [PubMed]

61. Bedi, B.; Mead, J.R. Cryptosporidium parvum antigens induce mouse and human dendritic cells to generate Th1-enhancing cytokines. Parasite Immunol. 2012, 34, 473-485. [CrossRef] [PubMed]

62. Murphy, K.P.; Travers, P.; Walport, M.; Janeway, C. Janeway's Immunobiology, 7th ed.; Garland Science: New York, NY, USA, 2008; 887p, ISBN 0815341237. 
63. Barakat, F.M.; McDonald, V.; Foster, G.R.; Tovey, M.G.; Korbel, D.S. Cryptosporidium parvum infection rapidly induces a protective innate immune response involving type I interferon. J. Infect. Dis. 2009, 200, 1548-1555. [CrossRef] [PubMed]

64. Urban, J.F., Jr.; Fayer, R.; Chen, S.J.; Gause, W.C.; Gately, M.K.; Finkelman, F.D. IL-12 protects immunocompetent and immunodeficient neonatal mice against infection with Cryptosporidium parvum. J. Immunol. 1996, 156, 263-268. [PubMed]

65. McDonald, V.; Pollok, R.C.; Dhaliwal, W.; Naik, S.; Farthing, M.J.; Bajaj-Elliott, M. A potential role for interleukin-18 in inhibition of the development of Cryptosporidium parvum. Clin. Exp. Immunol. 2006, 145, 555-562. [CrossRef] [PubMed]

66. Von Oettingen, J.; Nath-Chowdhury, M.; Ward, B.J.; Rodloff, A.C.; Arrowood, M.J.; Ndao, M. High-yield amplification of Cryptosporidium parvum in interferon gamma receptor knockout mice. Parasitology 2008, 135, 1151-1156. [CrossRef] [PubMed]

67. Ndao, M.; Nath-Chowdhury, M.; Sajid, M.; Marcus, V.; Mashiyama, S.T.; Sakanari, J.; Chow, E.; Mackey, Z.; Land, K.M.; Jacobson, M.P.; et al. A cysteine protease inhibitor rescues mice from a lethal Cryptosporidium parvum infection. Antimicrob. Agents Chemother. 2013, 57, 6063-6073. [CrossRef] [PubMed]

68. Sonzogni-Desautels, K.; Renteria, A.E.; Camargo, F.V.; Di Lenardo, T.Z.; Mikhail, A.; Arrowood, M.J.; Fortin, A.; Ndao, M. Oleylphosphocholine (OlPC) arrests Cryptosporidium parvum growth in vitro and prevents lethal infection in interferon gamma receptor knock-out mice. Front. Microbiol. 2015, 6, 973. [CrossRef] [PubMed]

69. Lean, I.S.; McDonald, V.; Pollok, R.C. The role of cytokines in the pathogenesis of Cryptosporidium infection. Curr. Opin. Infect. Dis. 2002, 15, 229-234. [CrossRef] [PubMed]

70. Tessema, T.S.; Schwamb, B.; Lochner, M.; Forster, I.; Jakobi, V.; Petry, F. Dynamics of gut mucosal and systemic Th1/Th2 cytokine responses in interferon-gamma and interleukin-12p40 knock out mice during primary and challenge Cryptosporidium parvum infection. Immunobiology 2009, 214, 454-466. [CrossRef] [PubMed]

71. Jakobi, V.; Petry, F. Humoral immune response in IL-12 and IFN-gamma deficient mice after infection with Cryptosporidium paroum. Parasite Immunol. 2008, 30, 151-161. [CrossRef] [PubMed]

72. Forchielli, M.; Walker, A.W. The role of gut-associated lymphoid tissues and mucosal defence. Br. J. Nutr. 2005, 93, S41-S48. [CrossRef] [PubMed]

73. Lozupone, C.A.; Stombaugh, J.I.; Gordon, J.I.; Jansson, J.K.; Knight, R. Diversity, stability and resilience of the human gut microbiota. Nature 2012, 489, 220-230. [CrossRef] [PubMed]

74. Koboziev, I.; Karlsson, F.; Grisham, M.B. Gut-associated lymphoid tissue, T cell trafficking, and chronic intestinal inflammation. Ann. N. Y. Acad. Sci. 2010, 1207, E86-E93. [CrossRef] [PubMed]

75. Neurath, M.F.; Finotto, S.; Glimcher, L.H.; Neurath, M.F.; Finotto, S.; Glimcher, L.H. The role of Th1/Th2 polarization in mucosal immunity. Nat. Med. 2002, 8, 567-583. [CrossRef] [PubMed]

76. Hunter, P.R.; Nichols, G. Epidemiology and clinical features of Cryptosporidium infection in immunocompromised patients. Clin. Microbiol. Rev. 2002, 15, 145-154. [CrossRef] [PubMed]

77. Nsagha, D.S.; Njunda, A.L.; Assob, N.J.; Ayima, C.W.; Tanue, E.A.; Kibu, O.D.; Kwenti, T.E. Intestinal parasitic infections in relation to CD4(+) T cell counts and diarrhea in HIV / AIDS patients with or without antiretroviral therapy in Cameroon. BMC Infect. Dis. 2016, 16, 9. [CrossRef] [PubMed]

78. Pozio, E.; Rezza, G.; Boschini, A.; Pezzotti, P.; Tamburrini, A.; Rossi, P.; Fine, D.M.; Smacchia, C.; Schiesari, A.; Gattei, E.; et al. Clinical cryptosporidiosis and human immunodeficiency virus (HIV)-induced immunosuppression: Findings from a longitudinal study of HIV-positive and HIV-negative former injection drug users. J. Infect. Dis. 1997, 176, 969-975. [CrossRef] [PubMed]

79. Rashmi, K.S.; Ravi Kumar, K.L. Intestinal cryptosporidiosis and the profile of the CD4 counts in a cohort of HIV infected patients. J. Clin. Diagn. Res. 2013, 7, 1016-1020. [CrossRef]

80. Gedle, D.; Kumera, G.; Eshete, T.; Ketema, K.; Adugna, H.; Feyera, F. Intestinal parasitic infections and its association with undernutrition and CD4 T cell levels among HIV / AIDS patients on HAART in Butajira, Ethiopia. J. Health Popul. Nutr. 2017, 36, 15. [CrossRef] [PubMed]

81. Weber, D.J.; Rutala, W.A. Cryptosporidiosis. N. Engl. J. Med. 2002, 347, 1287. [CrossRef] [PubMed]

82. Huang, D.B.; White, C.A. An updated review on Cryptosporidium and Giardia. Gastroenterol. Clin. N. Am. 2006, 35, 291-314. [CrossRef] [PubMed] 
83. Zhao, G.H.; Fang, Y.Q.; Ryan, U.; Guo, Y.X.; Wu, F.; Du, S.Z.; Chen, D.K.; Lin, Q. Dynamics of Th17 associating cytokines in Cryptosporidium parvum-infected mice. Parasitol. Res. 2016, 115, 879-887. [CrossRef] [PubMed]

84. Kindt, T.J.; Goldsby, R.A.; Osborne, B.A.; Kuby, J. Kuby Immunology, 6th ed.; W.H. Freeman: New York, NY, USA, 2007; 693p, ISBN 9781429202114.

85. Marchi, L.F.; Sesti-Costa, R.; Ignacchiti, M.D.; Chedraoui-Silva, S.; Mantovani, B. In vitro activation of mouse neutrophils by recombinant human interferon-gamma: Increased phagocytosis and release of reactive oxygen species and pro-inflammatory cytokines. Int. Immunopharmacol. 2014, 18, 228-235. [CrossRef] [PubMed]

86. Diamond, R.D.; Lyman, C.A.; Wysong, D.R. Disparate effects of interferon-gamma and tumor necrosis factor-alpha on early neutrophil respiratory burst and fungicidal responses to Candida albicans hyphae in vitro. J. Clin. Investig. 1991, 87, 711-720. [CrossRef] [PubMed]

87. Maródi, L.; Káposzta, R.; Nemes, E. Survival of group B streptococcus type III in mononuclear phagocytes: Differential regulation of bacterial killing in cord macrophages by human recombinant gamma interferon and granulocyte-macrophage colony-stimulating factor. Infect. Immun. 2000, 68, 2167-2170. [CrossRef] [PubMed]

88. Aguirre, S.A.; Perryman, L.E.; Davis, W.C.; McGuire, T.C. IL-4 protects adult C57BL/6 mice from prolonged Cryptosporidium parvum infection: Analysis of CD4 + alpha beta + IFN-gamma + and CD4 + alpha beta + IL-4 + lymphocytes in gut-associated lymphoid tissue during resolution of infection. J. Immunol. 1998, 161, 1891-1900. [PubMed]

89. McDonald, S.A.; O'Grady, J.E.; Bajaj-Elliott, M.; Notley, C.A.; Alexander, J.; Brombacher, F.; McDonald, V. Protection against the early acute phase of Cryptosporidium parvum infection conferred by interleukin-4-induced expression of T helper 1 cytokines. J. Infect. Dis. 2004, 190, 1019-1025. [CrossRef] [PubMed]

90. Biedermann, T.; Zimmermann, S.; Himmelrich, H.; Gumy, A.; Egeter, O.; Sakrauski, A.K.; Seegmuller, I.; Voigt, H.; Launois, P.; Levine, A.D.; et al. IL-4 instructs TH1 responses and resistance to Leishmania major in susceptible BALB/c mice. Nat. Immunol. 2001, 2, 1054-1060. [CrossRef] [PubMed]

91. Pantenburg, B.; Castellanos-Gonzalez, A.; Dann, S.M.; Connelly, R.L.; Lewis, D.E.; Ward, H.D.; White, A.C. Human CD8(+) T cells clear Cryptosporidium parvum from infected intestinal epithelial cells. Am. J. Trop. Med. Hyg. 2010, 82, 600-607. [CrossRef] [PubMed]

92. Chen, W.; Harp, J.A.; Harmsen, A.G. Requirements for CD4+ cells and gamma interferon in resolution of established Cryptosporidium parvum infection in mice. Infect. Immun. 1993, 61, 3928-3932. [PubMed]

93. McDonald, V.; Robinson, H.A.; Kelly, J.P.; Bancroft, G.J. Immunity to Cryptosporidium muris infection in mice is expressed through gut CD4+ intraepithelial lymphocytes. Infect. Immun. 1996, 64, 2556-2562. [PubMed]

94. McDonald, V.; Robinson, H.A.; Kelly, J.P.; Bancroft, G.J. Cryptosporidium muris in adult mice: Adoptive transfer of immunity and protective roles of CD4 versus CD8 cells. Infect. Immun. 1994, 62, 2289-2294. [PubMed]

95. Brandtzaeg, P. Mucosal immunity: Induction, dissemination, and effector functions. Scand. J. Immunol. 2009, 70, 505-515. [CrossRef] [PubMed]

96. Wesemann, D.R.; Portuguese, A.J.; Meyers, R.M.; Gallagher, M.P.; Cluff-Jones, K.; Magee, J.M.; Panchakshari, R.A.; Rodig, S.J.; Kepler, T.B.; Alt, F.W. Microbial colonization influences early B-lineage development in the gut lamina propria. Nature 2013, 501, 112-115. [CrossRef] [PubMed]

97. Macpherson, A.J.; Geuking, M.B.; Slack, E.; Hapfelmeier, S.; McCoy, K.D. The habitat, double life, citizenship, and forgetfulness of IgA. Immunol. Rev. 2012, 245, 132-146. [CrossRef] [PubMed]

98. Kassa, M.; Comby, E.; Lemeteil, D.; Brasseur, P.; Ballet, J.J. Characterization of anti-Cryptosporidium IgA antibodies in sera from immunocompetent individuals and HIV-infected patients. J. Protozool. 1991, 38, 179S-180S. [PubMed]

99. Allison, G.M.; Rogers, K.A.; Borad, A.; Ahmed, S.; Karim, M.; Kane, A.V.; Hibberd, P.L.; Naumova, E.N.; Calderwood, S.B.; Ryan, E.T.; et al. Antibody responses to the immunodominant Cryptosporidium gp15 antigen and gp15 polymorphisms in a case-control study of cryptosporidiosis in children in Bangladesh. Am. J. Trop. Med. Hyg. 2011, 85, 97-104. [CrossRef] [PubMed] 
100. Borad, A.J.; Allison, G.M.; Wang, D.; Ahmed, S.; Karim, M.M.; Kane, A.V.; Moy, J.; Hibberd, P.L.; Ajjampur, S.; Kang, G.; et al. Systemic antibody responses to the immunodominant p23 antigen and p23 polymorphisms in children with cryptosporidiosis in Bangladesh. Am. J. Trop. Med. Hyg. 2012, 86, 214-222. [CrossRef] [PubMed]

101. Mead, J.R. Prospects for immunotherapy and vaccines against Cryptosporidium. Hum. Vaccines Immunother. 2014, 10, 1505-1513. [CrossRef] [PubMed]

102. Steele, J.; Sponseller, J.; Schmidt, D.; Cohen, O.; Tzipori, S. Hyperimmune bovine colostrum for treatment of GI infections. Hum. Vaccines Immunother. 2013, 9, 1565-1568. [CrossRef] [PubMed]

103. Kramski, M.; Center, R.J.; Wheatley, A.K.; Jacobson, J.C.; Alexander, M.R.; Rawlin, G.; Purcell, D.F. Hyperimmune bovine colostrum as a low-cost, large-scale source of antibodies with broad neutralizing activity for HIV-1 envelope with potential use in microbicides. Antimicrob. Agents Chemother. 2012, 56, 4310-4319. [CrossRef] [PubMed]

104. Naciri, M.; Mancassola, R.; Reperant, J.M.; Canivez, O.; Quinque, B.; Yvore, P. Treatment of experimental ovine cryptosporidiosis with ovine or bovine hyperimmune colostrum. Vet. Parasitol. 1994, 53, 173-190. [CrossRef]

105. Wyatt, C.R.; Brackett, E.J.; Savidge, J. Evidence for the emergence of a type-1-like immune response in intestinal mucosa of calves recovering from cryptosporidiosis. J. Parasitol. 2001, 87, 90-95. [CrossRef] [PubMed]

106. Wyatt, C.R.; Barrett, W.J.; Brackett, E.J.; Schaefer, D.A.; Riggs, M.W. Association of IL-10 expression by mucosal lymphocytes with increased expression of Cryptosporidium paroum epitopes in infected epithelium. J. Parasitol. 2002, 88, 281-286. [CrossRef]

107. Wyatt, C.R.; Lindahl, S.; Austin, K.; Kapil, S.; Branch, J. Response of T lymphocytes from previously infected calves to recombinant Cryptosporidium parvum P23 vaccine antigen. J. Parasitol. 2005, 91, 1239-1242. [CrossRef] [PubMed]

108. Whitmire, W.M.; Harp, J.A. Characterization of bovine cellular and serum antibody responses during infection by Cryptosporidium parvum. Infect. Immun. 1991, 59, 990-995. [PubMed]

109. De Graaf, D.C.; Peeters, J.E. Specific interferon-gamma, IgA and IgM responses after experimental infection of neonatal calves with Cryptosporidium parvum. Int. J. Parasitol. 1997, 27, 131-134. [CrossRef]

110. Peeters, J.E.; Villacorta, I.; Vanopdenbosch, E.; Vandergheynst, D.; Naciri, M.; Ares-Mazas, E.; Yvore, P. Cryptosporidium paroum in calves: Kinetics and immunoblot analysis of specific serum and local antibody responses (immunoglobulin A [IgA], IgG, and $\operatorname{IgM}$ ) after natural and experimental infections. Infect. Immun. 1992, 60, 2309-2316. [PubMed]

111. Wyatt, C.R.; Brackett, E.J.; Mason, P.H.; Savidge, J.; Perryman, L.E. Excretion patterns of mucosally delivered antibodies to p23 in Cryptosporidium parvum infected calves. Vet. Immunol. Immunopathol. 2000, 76, 309-317. [CrossRef]

112. Wyatt, C.R.; Perryman, L.E. Detection of mucosally delivered antibody to Cryptosporidium parvum p23 in infected calves. Ann. N. Y. Acad. Sci. 2000, 916, 378-387. [CrossRef] [PubMed]

113. Wang, H.F.; Swain, J.B.; Besser, T.E.; Jasmer, D.; Wyatt, C.R. Detection of antibodies to a recombinant Cryptosporidium parvum $\mathrm{p} 23$ in serum and feces from neonatal calves. J. Parasitol. 2003, 89, 918-923. [CrossRef] [PubMed]

114. Foster, D.M.; Smith, G.W. Pathophysiology of diarrhea in calves. Vet. Clin. N. Am. Food Anim. Pract. 2009, 25, 13-36. [CrossRef] [PubMed]

115. Perryman, L.E.; Kapil, S.J.; Jones, M.L.; Hunt, E.L. Protection of calves against cryptosporidiosis with immune bovine colostrum induced by a Cryptosporidium parvum recombinant protein. Vaccine 1999, 17, 2142-2149. [CrossRef]

116. Askari, N.; Shayan, P.; Mokhber-Dezfouli, M.R.; Ebrahimzadeh, E.; Lotfollahzadeh, S.; Rostami, A.; Amininia, N.; Ragh, M.J. Evaluation of recombinant P23 protein as a vaccine for passive immunization of newborn calves against Cryptosporidium parvum. Parasite Immunol. 2016, 38, 282-289. [CrossRef] [PubMed]

117. Tatalick, L.M.; Perryman, L.E. Attempts to protect severe combined immunodeficient (SCID) mice with antibody enriched for reactivity to Cryptosporidium parvum surface antigen-1. Vet. Parasitol. 1995, 58, 281-290. [CrossRef]

118. Perryman, L.E.; Kegerris, K.A.; Mason, P.H. Effect of orally administered monoclonal antibody on persistent Cryptosporidium paroum infection in scid mice. Infect. Immun. 1993, 61, 4906-4908. [PubMed] 
119. Riggs, M.W.; Schaefer, D.A.; Kapil, S.J.; Barley-Maloney, L.; Perryman, L.E. Efficacy of monoclonal antibodies against defined antigens for passive immunotherapy of chronic gastrointestinal cryptosporidiosis. Antimicrob. Agents Chemother. 2002, 46, 275-282. [CrossRef] [PubMed]

120. Enriquez, F.J.; Riggs, M.W. Role of immunoglobulin A monoclonal antibodies against P23 in controlling murine Cryptosporidium parvum infection. Infect. Immun. 1998, 66, 4469-4473. [PubMed]

121. Kobayashi, C.; Yokoyama, H.; Nguyen, S.V.; Kodama, Y.; Kimata, T.; Izeki, M. Effect of egg yolk antibody on experimental Cryptosporidium parvum infection in scid mice. Vaccine 2004, 23, 232-235. [CrossRef] [PubMed]

122. Riggs, M.W.; Cama, V.A.; Leary, H.L., Jr.; Sterling, C.R. Bovine antibody against Cryptosporidium parvum elicits a circumsporozoite precipitate-like reaction and has immunotherapeutic effect against persistent cryptosporidiosis in SCID mice. Infect. Immun. 1994, 62, 1927-1939. [PubMed]

123. Martin-Gomez, S.; Alvarez-Sanchez, M.A.; Rojo-Vazquez, F.A. Oral administration of hyperimmune anti-Cryptosporidium paroum ovine colostral whey confers a high level of protection against cryptosporidiosis in newborn NMRI mice. J. Parasitol. 2005, 91, 674-678. [CrossRef] [PubMed]

124. Adjei, A.A.; Jones, J.T.; Riggs, M.W.; Enriquez, F.J. Evidence of thymus-independent local and systemic antibody responses to Cryptosporidium parvum infection in nude mice. Infect. Immun. 1999, 67, 3947-3951. [PubMed]

125. Cozon, G.; Biron, F.; Jeannin, M.; Cannella, D.; Revillard, J.P. Secretory IgA antibodies to Cryptosporidium parvum in AIDS patients with chronic cryptosporidiosis. J. Infect. Dis. 1994, 169, 696-699. [CrossRef] [PubMed]

126. Tzipori, S.; Roberton, D.; Chapman, C. Remission of diarrhoea due to cryptosporidiosis in an immunodeficient child treated with hyperimmune bovine colostrum. Br. Med. J. (Clin. Res. Ed.) 1986, 293, 1276-1277. [CrossRef]

127. Plettenberg, A.; Stoehr, A.; Stellbrink, H.J.; Albrecht, H.; Meigel, W. A preparation from bovine colostrum in the treatment of HIV-positive patients with chronic diarrhea. Clin. Investig. 1993, 71, 42-45. [CrossRef] [PubMed]

128. Greenberg, P.D.; Cello, J.P. Treatment of severe diarrhea caused by Cryptosporidium parvum with oral bovine immunoglobulin concentrate in patients with AIDS. J. Acquir. Immune Defic. Syndr. 1996, 13, 348-354. [CrossRef]

129. Nord, J.; Ma, P.; DiJohn, D.; Tzipori, S.; Tacket, C.O. Treatment with bovine hyperimmune colostrum of cryptosporidial diarrhea in AIDS patients. AIDS 1990, 4, 581-584. [CrossRef]

130. Abubakar, I.; Aliyu, S.H.; Arumugam, C.; Hunter, P.R.; Usman, N.K. Prevention and treatment of cryptosporidiosis in immunocompromised patients. Cochrane Database Syst. Rev. 2007, CD004932. [CrossRef] [PubMed]

131. Plotkin, S. History of vaccination. Proc. Natl. Acad. Sci. USA 2014, 111, 12283-12287. [CrossRef] [PubMed]

132. Pulendran, B.; Ahmed, R. Immunological mechanisms of vaccination. Nat. Immunol. 2011, $12,509-517$. [CrossRef] [PubMed]

133. Yu, Q.; Li, J.; Zhang, X.; Gong, P.; Zhang, G.; Li, S.; Wang, H. Induction of immune responses in mice by a DNA vaccine encoding Cryptosporidium parvum Cp12 and Cp21 and its effect against homologous oocyst challenge. Vet. Parasitol. 2010, 172, 1-7. [CrossRef] [PubMed]

134. Wang, C.; Luo, J.; Amer, S.; Guo, Y.; Hu, Y.; Lu, Y.; Wang, H.; Duan, M.; He, H. Multivalent DNA vaccine induces protective immune responses and enhanced resistance against Cryptosporidium parvum infection. Vaccine 2010, 29, 323-328. [CrossRef] [PubMed]

135. He, H.; Zhao, B.; Liu, L.; Zhou, K.; Qin, X.; Zhang, Q.; Li, X.; Zheng, C.; Duan, M. The humoral and cellular immune responses in mice induced by DNA vaccine expressing the sporozoite surface protein of Cryptosporidium parvum. DNA Cell Biol. 2004, 23, 335-339. [CrossRef] [PubMed]

136. Boulter-Bitzer, J.I.; Lee, H.; Trevors, J.T. Molecular targets for detection and immunotherapy in Cryptosporidium parvum. Biotechnol. Adv. 2007, 25, 13-44. [CrossRef] [PubMed]

137. Burton, A.J.; Nydam, D.V.; Jones, G.; Zambriski, J.A.; Linden, T.C.; Cox, G.; Davis, R.; Brown, A.; Bowman, D.D. Antibody responses following administration of a Cryptosporidium parvum rCP15/60 vaccine to pregnant cattle. Vet. Parasitol. 2011, 175, 178-181. [CrossRef] [PubMed]

138. Liu, K.; Zai, D.; Zhang, D.; Wei, Q.; Han, G.; Gao, H.; Huang, B. Divalent Cp15-23 vaccine enhances immune responses and protection against Cryptosporidium parvum infection. Parasite Immunol. 2010, 32, 335-344. [CrossRef] [PubMed] 
139. Hoffman, S.L.; Billingsley, P.F.; James, E.; Richman, A.; Loyevsky, M.; Li, T.; Chakravarty, S.; Gunasekera, A.; Chattopadhyay, R.; Li, M.; et al. Development of a metabolically active, non-replicating sporozoite vaccine to prevent Plasmodium falciparum malaria. Hum. Vaccines 2010, 6, 97-106. [CrossRef]

140. Williams, R.B. Fifty years of anticoccidial vaccines for poultry (1952-2002). Avian Dis. 2002, 46, 775-802. [CrossRef]

141. McDonald, V.; Shirley, M.W. Past and future: Vaccination against Eimeria. Parasitology 2009, 136, 1477-1489. [CrossRef] [PubMed]

142. Jenkins, M.C.; Chute, M.B.; Danforth, H.D. Protection against coccidiosis in outbred chickens elicited by gamma-irradiated Eimeria maxima. Avian Dis. 1997, 41, 702-708. [CrossRef] [PubMed]

143. Wilkins, M.F.; O'Connell, E.; Te Punga, W.A. Toxoplasmosis in sheep III. Further evaluation of the ability of a live Toxoplasma gondii vaccine to prevent lamb losses and reduce congenital infection following experimental oral challenge. N. Z. Vet. J. 1988, 36, 86-89. [CrossRef] [PubMed]

144. Buxton, D.; Thomson, K.; Maley, S.; Wright, S.; Bos, H. Experimental challenge of sheep 18 months after vaccination with a live (S48) Toxoplasma gondii vaccine. Vet. Rec. 1993, 133, 310-312. [CrossRef] [PubMed]

145. Dunning, N. Leishmania vaccines: From leishmanization to the era of DNA technology. Biosci. Horiz. Int. J. Stud. Res. 2009, 2, 73-82. [CrossRef]

146. Breton, M.; Tremblay, M.J.; Ouellette, M.; Papadopoulou, B. Live nonpathogenic parasitic vector as a candidate vaccine against visceral leishmaniasis. Infect. Immun. 2005, 73, 6372-6382. [CrossRef] [PubMed]

147. Bhattacharya, P.; Dey, R.; Dagur, P.K.; Kruhlak, M.; Ismail, N.; Debrabant, A.; Joshi, A.B.; Akue, A.; Kukuruga, M.; Takeda, K.; et al. Genetically modified live attenuated Leishmania donovani parasites induce innate immunity through classical activation of macrophages that direct the Th1 response in mice. Infect. Immun. 2015, 83, 3800-3815. [CrossRef] [PubMed]

148. Arrowood, M.J. In vitro cultivation of cryptosporidium species. Clin. Microbiol. Rev. 2002, 15, 390-400. [CrossRef] [PubMed]

149. Yu, J.R.; Park, W.Y. The effect of gamma-irradiation on the viability of Cryptosporidium parvum. J. Parasitol. 2003, 89, 639-642. [CrossRef]

150. Jenkins, M.; Higgins, J.; Kniel, K.; Trout, J.; Fayer, R. Protection of calves against cryptosporiosis by oral inoculation with gamma-irradiated Cryptosporidium parvum oocysts. J. Parasitol. 2004, 90, 1178-1180. [CrossRef] [PubMed]

151. Schafer, R.; Portnoy, D.A.; Brassell, S.A.; Paterson, Y. Induction of a cellular immune response to a foreign antigen by a recombinant Listeria monocytogenes vaccine. J. Immunol. 1992, 149, 53-59. [PubMed]

152. Guy, B.; Guirakhoo, F.; Barban, V.; Higgs, S.; Monath, T.P.; Lang, J. Preclinical and clinical development of YFV 17D-based chimeric vaccines against dengue, West Nile and Japanese encephalitis viruses. Vaccine 2010, 28, 632-649. [CrossRef] [PubMed]

153. Galen, J.E.; Pasetti, M.F.; Tennant, S.; Ruiz-Olvera, P.; Sztein, M.B.; Levine, M.M. Salmonella enterica serovar Typhi live vector vaccines finally come of age. Immunol. Cell Biol. 2009, 87, 400-412. [CrossRef] [PubMed]

154. Hathaway, L.J.; Kraehenbuhl, J.P. The role of M cells in mucosal immunity. Cell. Mol. Life Sci. 2000, 57, 323-332. [CrossRef] [PubMed]

155. Manque, P.A.; Tenjo, F.; Woehlbier, U.; Lara, A.M.; Serrano, M.G.; Xu, P.; Alves, J.M.; Smeltz, R.B.; Conrad, D.H.; Buck, G.A. Identification and immunological characterization of three potential vaccinogens against Cryptosporidium species. Clin. Vaccine Immunol. 2011, 18, 1796-1802. [CrossRef] [PubMed]

156. Benitez, A.J.; McNair, N.; Mead, J.R. Oral immunization with attenuated Salmonella enterica serovar Typhimurium encoding Cryptosporidium parvum $\mathrm{Cp} 23$ and $\mathrm{Cp} 40$ antigens induces a specific immune response in mice. Clin. Vaccine Immunol. 2009, 16, 1272-1278. [CrossRef] [PubMed]

157. Roche, J.K.; Rojo, A.L.; Costa, L.B.; Smeltz, R.; Manque, P.; Woehlbier, U.; Bartelt, L.; Galen, J.; Buck, G.; Guerrant, R.L. Intranasal vaccination in mice with an attenuated Salmonella enterica Serovar 908htr A expressing Cp15 of Cryptosporidium: Impact of malnutrition with preservation of cytokine secretion. Vaccine 2013, 31, 912-918. [CrossRef] [PubMed]

158. Carleton, H.A. Pathogenic bacteria as vaccine vectors: Teaching old bugs new tricks. Yale J. Biol. Med. 2010, 83, 217-222. [PubMed]

159. Pei, Z.; Jiang, X.; Yang, Z.; Ren, X.; Gong, H.; Reeves, M.; Sheng, J.; Wang, Y.; Pan, Z.; Liu, F.; et al. Oral delivery of a novel attenuated Salmonella vaccine expressing Influenza A virus proteins protects mice against H5N1 and H1N1 viral infection. PLoS ONE 2015, 10, e0129276. [CrossRef] [PubMed] 
160. Wang, L.; Wang, X.; Bi, K.; Sun, X.; Yang, J.; Gu, Y.; Huang, J.; Zhan, B.; Zhu, X. Oral vaccination with attenuated Salmonella typhimurium-delivered TsPmy DNA vaccine elicits protective immunity against Trichinella spiralis in BALB/c mice. PLoS Negl. Trop. Dis. 2016, 10, e0004952. [CrossRef] [PubMed]

161. Chinchilla, M.; Pasetti, M.F.; Medina-Moreno, S.; Wang, J.; Gomez-Duarte, O.G.; Stout, R.; Levine, M.M.; Galen, J.E. Enhanced immunity to Plasmodium falciparum circumsporozoite protein (PfCSP) by using Salmonella enterica serovar Typhi expressing PfCSP and a PfCSP-encoding DNA vaccine in a heterologous prime-boost strategy. Infect. Immun. 2007, 75, 3769-3779. [CrossRef] [PubMed]

162. Shahabi, V.; Maciag, P.C.; Rivera, S.; Wallecha, A. Live, attenuated strains of Listeria and Salmonella as vaccine vectors in cancer treatment. Bioeng. Bugs 2010, 1, 235-243. [CrossRef] [PubMed]

163. Hegazy, W.; Xu, X.; Metelitsa, L.; Hensel, M. Evaluation of Salmonella enterica type III secretion system effector proteins as carriers for heterologous vaccine antigens. Infect. Immun. 2012, 80, 1193-1202. [CrossRef] [PubMed]

164. Shirafuji, H.; Xuan, X.; Kimata, I.; Takashima, Y.; Fukumoto, S.; Otsuka, H.; Nagasawa, H.; Suzuki, H. Expression of P23 of Cryptosporidium parvum in Toxoplasma gondii and evaluation of its protective effects. J. Parasitol. 2005, 91, 476-479. [CrossRef] [PubMed]

165. Stevens, T.L.; Bossie, A.; Sanders, V.M.; Fernandez-Botran, R.; Coffman, R.L.; Mosmann, T.R.; Vitetta, E.S. Regulation of antibody isotype secretion by subsets of antigen-specific helper T cells. Nature 1988, 334, 255-258. [CrossRef] [PubMed]

166. Kwok, L.Y.; Wang, L.; Zhang, J.; Guo, Z.; Zhang, H. A pilot study on the effect of Lactobacillus casei Zhang on intestinal microbiota parameters in Chinese subjects of different age. Benef. Microbes 2014, 5, 295-304. [CrossRef] [PubMed]

167. Geriletu; Xu, R.; Jia, H.; Terkawi, M.A.; Xuan, X.; Zhang, H. Immunogenicity of orally administrated recombinant Lactobacillus casei Zhang expressing Cryptosporidium parvum surface adhesion protein P23 in mice. Curr. Microbiol. 2011, 62, 1573-1580. [CrossRef]

168. Lin, I.Y.C.; Van, T.; Smooker, P.M. Live-attenuated bacterial vectors: Tools for vaccine and therapeutic agent delivery. Vaccines 2015, 3, 940-972. [CrossRef] [PubMed]

169. Shin, H.; Iwasaki, A. A vaccine strategy that protects against genital herpes by establishing local memory $\mathrm{T}$ cells. Nature 2012, 491, 463-467. [CrossRef] [PubMed]

(c) 2017 by the authors. Licensee MDPI, Basel, Switzerland. This article is an open access article distributed under the terms and conditions of the Creative Commons Attribution (CC BY) license (http:/ / creativecommons.org/licenses/by/4.0/). 